\title{
Mock elections as a way to cultivate democratic development and a democratic school culture
}

\author{
Isolde de Groot* and Bram Eidhof - University of Humanistic Studies, \\ The Netherlands
}

\begin{abstract}
Over the last decades, many European Union countries have invested in strengthening participatory learning in citizenship education policy and practice. This survey study provides insight into how high school teachers in the Netherlands advance critical democratic citizenship and a democratic school culture in the context of mock elections. A quarter of the schools that organized mock elections in 2017 participated in the study. Analysis reveals that attention for critical, valuerelated teacher aims and teacher aims directed at strengthening a democratic school culture is still limited in mock election-related education. It also shows that half of the participating schools offer less than one hour of mock electionrelated educational activities, and that one-third of the teachers would like to offer additional educational activities.
\end{abstract}

Keywords: Democratic education, mock elections, democratic school culture, secondary education

\section{Introduction}

Over the last decades, many member states of the European Union (EU) have invested in strengthening participatory learning in citizenship education policy and practice (Veugelers et al., 2017). The underlying premises are that children are not born as democratic citizens, that schools are mini-societies where students can experience or unlearn - democracy, that students have a right to be heard in (school) matters that affect their lives, and that informed participation in democratic practices within school and beyond can spur enlightened democratic engagement in later life (see, for example, Biesta, 2011; Dewey, 1916; Shier, 2001; Parker, 2003).

In the Netherlands, where this study is situated, the government installed legal obligations for schools to foster 'active participation and social integration' of primary and secondary education students in 2006 (Ministry of Education, 2006). In practice, this means that schools need to advance specific learning goals (for example, 'students learn to behave in line with general accepted norms and values'). The Dutch government does not mandate schools to offer a specific course or subject on citizenship. Instead, citizenship is to be offered in an integrative manner. In secondary education, students attend the mandatory one year Study of Society course, which is typically offered in the pre-final year. For vocational education, attended by students who have finished the pre-vocational track 1-4 in secondary education (about half of the Dutch student population, aged 16-20), no learning goals are set.

To complement the 2006 standards, the government recently introduced additional legislation (for example, on diversity education and teacher education in 
civics). In addition, it is supporting the further development of curriculum materials, experiential learning activities and measurement tools. Ten years after the introduction of educational legislation that obliges schools in primary and secondary education to prepare students for participation in the Dutch democratic and pluralist society, however, citizenship education practice does not live up to public and political expectations (Dekker, 2015; Educational Inspectorate, 2016). A recent study that examined the policy and practice of teaching democracy and tolerance in all $28 \mathrm{EU}$ member states revealed that citizenship education policy and practices in the Netherlands are mediocre when compared with the other member states (Veugelers et al., 2017). Likewise, the new International Civic and Citizenship Education Study (ICCS), which examines citizenship development among 14-year-olds, revealed that Dutch 14-year-olds have limited knowledge about democracy and the rule of law. They also score lower on political engagement and inclination to vote, compared with their peers in related EU countries (Munniksma et al., 2017). Possible explanations offered in these reports are the limited attention for democracy in educational legislation and in the core curriculum; limited opportunities to practise democratic skills; omissions in (post-)initial teacher training; and the level of school segregation in the Netherlands.

Existing surveys on citizenship development and education in secondary education, such as the ICCS (Losito et al., 2018) have yielded insight into whether or not specific practices, such as student councils, are widespread across countries. However, these studies do not provide an insight into the quality of the participatory practices offered and related education. In this study, we set out to gain further insight into one specific democratic practice: mock elections, which are the shadow elections that schools sometimes organize prior to official elections. We hereby focus on secondary education, the school level that has the strongest tradition of organizing mock elections.

While mock elections have been organized for decades in many EU countries and US states, there is limited published research in this area. There is some evidence that mock elections and related political educational activities, especially when organized in higher secondary education, stimulate political engagement in later life (Keating and Janmaat, 2016), and scholars have pointed to the value of election simulations in offering meaningful and robust political education (Parker and Lo, 2016). So far, however, scholars have not examined the type of developments that teachers actually pursue in the context of mock elections, both at the level of the individual student and at the level of school culture. To what extent, for instance, do schools aim to cultivate students' ability to consolidate democratic values in society through voting for certain candidates and parties? To what extent do teachers envision mock elections as a venue to stimulate a democratic school culture? We also do not know what type of educational activities schools organize prior to and following the elections, how educational activities vary among pre-university and pre-vocational tracks, and how educational activities vary among the dominant school types in the Netherlands: prevocational schools, pre-university schools and comprehensive schools, the latter offering both pre-university and pre-vocational tracks.

Complementing an earlier, qualitative study into mock elections and related education in 2012 (De Groot, 2017, 2018a), this article reports a survey into how Dutch high school teachers advance, and intend to advance, critical democratic citizenship and a democratic school culture in the context of mock elections, and the constraints that teachers identify in this effort. In particular, it presents our findings on teacher aims and on the educational activities offered. While we do not know if attention to these components in the context of mock elections is representative for attention 
to these components in democratic participatory practices in general, insight into mock elections in schools may enrich public and political debate about the quality of participatory democratic and educational practices in schools. In addition, this study contributes to the development of questionnaires that measure systematic attention to value related components of political participatory practices in schools.

\section{Education for democracy: Key concepts and components}

Following insights about meaningful, project-based, democratic education and democratic participation, we determine the quality of critical democratic practices by the extent to which they: (a) target democratic competences of individuals as well as a democratic culture: this we here define as a way of life that, in line with democratic values, fosters respectful relations at the interpersonal level, and between groups of citizens, and seeks a more inclusive society (see, for example, De Groot and Veugelers, 2015); (b) utilize educational strategies that are known to be highly effective, for example, formative feedback and spiralling learning (Hattie, 2012); and (c) advance different modes of democratic student participation (Fielding and Moss, 2012; De Groot, 2018b). In light of these dimensions of critical democratic practices, this study pays particular attention to democratic values and a democratic culture in teacher aims and the educational activities that they organize in the context of mock elections. In this section, we explain our understanding of teachers' aims and educational activities.

Our study distinguishes between three main components of democratic development that teachers can pursue: knowledge, skills and attitude and identity (see also De Groot, 2013). In line with earlier definitions of these learning categories in (citizenship development and) education research (see, for example, Bloom, 1956; Carretero et al., 2015; Schulz et al., 2016; De Groot, 2017), knowledge concerns one's knowledge about, and understanding of, key concepts in citizenship education (such as democracy). Skills concern the cognitive capacities that enable participation in the civic and political domain (for example, the ability to analyse a civic issue in light of a certain theory) as well as participatory capacities (for example, deliberation skills). Attitudes are defined as the 'judgments or evaluations regarding ideas, persons, objects, events, situations, and/or relationships' (Schulz et al., 2016: 25), and citizenship identity concerns, among others, the stories that one develops about one's civic self and about one's participatory experiences (De Groot, 2018a). We also distinguish basic and critical aims. The term 'basic' refers to procedural and functional aims of democratic education and participation. Knowledge about the different steps of the election process is an example of basic democratic knowledge, while knowing how to cast one's vote is an example of an associated skill. Critical elements typically involve existential, moral or political questions and issues (for example, how (not) voting may impact one's daily life; what initiatives have been successful in balancing the influence of multinationals on tax and environmental policies). Also categorized under 'critical elements' are higher order thinking and participation skills (see, for example, Educational Research Service, 1997; Percy-Smith and Thomas, 2012). These more complex skills enable students to evaluate existing policies and practices in light of procedural or substantive criteria. Where the ability to navigate the political landscape is understood as a basic skill, the ability to evaluate party programmes on constitutional legislation and democratic principles and aspirations is an example of a critical skill. 
Research on effective learning strategies, deep learning, robust project-based learning and meaningful political participation has provided insight into educational strategies that can instigate learning processes in light of the basic and critical aims (see, for example, Barron et al., 1998; Hattie, 2012; Parker and Lo, 2016; Shier, 2001). Promising strategies in this regard include the setting of challenging aims, organizing opportunities for (formative) feedback, and careful selection of meaningful content. Typical educational activities that can accommodate such learning strategies in the context of mock elections are research assignments, reflection, design, evaluative and collaborative assignments on political events or programmes, well-designed deliberation and debating activities and assignments where students engage with stakeholders (by means of a visit or guest speaker).

\section{Data and methods}

To answer the main question of our quantitative inquiry, 'How do teachers in secondary education (intend to) advance critical democratic citizenship and a democratic school culture?', we explored teacher and school characteristics and the current and ideal situation of mock elections regarding aspects of mock elections that were also examined in a previous qualitative inquiry (De Groot, 2017, 2018b). Research questions formulated were:

1. How do teachers (intend to) pursue critical aims and a democratic school culture in the mock elections context?

2. How many hours do teachers (intend to) offer educational activities in the mock elections context, and what educational activities do teachers (intend to) organize?

3. How do teacher aims relate to teacher and school characteristics?

\section{Participants}

Our research population consists of all schools $(N=394)$ that participated in the national mock election programme of March 2017, which is about 60 per cent of the 638 Dutch high schools. This programme is facilitated by ProDemos, the nongovernmental organization (NGO) appointed by the Dutch Ministry of Education to stimulate democratic education at the national level. In this role, ProDemos provides schools with ballot papers for all participating students. Following the mock elections, which take place in the week prior to the official elections, ProDemos also analyses the votes casted anonymously across the country, and publishes overall voting results as well as results per school.

Because ProDemos did not file information about the school type when schools signed up for participation in a mock election, we had to control our sample for other school types. By checking the names of the schools, we identified ten vocational schools. Since vocational schools are not legally obliged to foster specific components of citizenship development, we did not include them in our sample.

Our study follows the Netherlands code of conduct for academic practice as defined by the Association of Universities in the Netherlands. Because the data management provisions at ProDemos were insufficient to organize the data collection from the institute, the data collection was outsourced to a third research organization (Elion).

To inform the coordinating teachers and school leaders (teachers hereafter) about the study, the survey was announced in the ProDemos newsletter. One teacher 
from each of the participating schools ( $N=384$ ) was invited to participate. They received an information letter and an invitation to participate in the study by email. This information letter contained an explanation of the aims and significance of the study, what participation entailed, how ethical standards were met and contact details of the principal investigator. Teachers consented to participate by answering the questionnaire. Two days after the elections, on Friday, 17 March, all 384 teachers received a unique code to complete the questionnaire. In the next three and a half weeks, two reminders were sent by email. When completing the list, teachers could win a coupon for the ProDemos website. From the teachers who received an invitation to participate in the survey, 46 per cent used the link to open the questionnaire. A total of 24 per cent of the teachers $(N=96)$ completed the questionnaire. The principal researcher then retrieved the anonymized data file and the key file from the secured data storage environment of Elion and administered both files to conform with university regulations (for example, storage of the key file in a separate location).

\section{Instruments}

We here discuss the sections of our questionnaire that are reported in this article: teacher and school characteristics, teacher aims and educational activities. To gain insight into teacher characteristics, we measured teacher gender $(\mathrm{m} / \mathrm{f})$, age, background (immigrant/not), educational background, main subject taught and number of years teaching civics and related courses. The following school characteristics were measured: school type, size of the student population, socioeconomic and cultural composition of the student population, school culture, school vision on citizenship/ political education and the school tradition in organizing mock elections. Regarding the latter, we examined the time when the school started organizing the elections (before/since 2001) and the types of elections offered (ProDemos facilitates mock elections in conjunction with local, provincial, national, international, referenda and the US elections).

Since we are the first to examine a specific participatory citizenship education practice (mock elections) from a critical democratic citizenship education perspective, we designed 43 items (all items are listed in Appendix 1) to measure teachers' aims relating to mock election education. Items that measure basic aims of democratic education (nine items) were derived from the International Civic and Citizenship Education Study (Schulz et al., 2016) and from the Dutch syllabi of social studies and social sciences (for example, 'insight into the main characteristics of parliamentary democracy'). Items that measure critical aims and aims directed at strengthening a democratic school culture were also derived from the Tool for quality assurance of education for democratic citizenship in schools (Bîrzea, 2005) and literature on critical democratic citizenship education and political participation (see, for example, Allen and Light, 2015; De Groot, 2018a, Fielding and Moss, 2012; Parker, 2003; Parker and Lo, 2016; Lo, 2017). The items addressed knowledge, skills, attitude and identity (Appendix 1). A five-point Likert-type scale was used to examine how much teachers attend to basic and complex aims (1: not at all; 2: a little bit; 3: some; 4: quite a lot; 5: a lot) in the context of mock elections. In relation to the general curriculum, we used a two-point scale to examine if teachers felt that little to no attention was paid to specific aims (1: no attention; 2: little attention).

The study also explored the educational activities that teachers offered prior to the elections and afterwards. Variables of interest (15 items) for this part of the study were derived from the Florida Civics Teacher Survey (2016), as well as from literature 
on project-based learning in civics (see, for example, Parker and Lo, 2016) and from activities described by teachers who participated in the qualitative study (De Groot, 2017). In the questionnaire, teachers were asked to tick the boxes of the activities that they organized. We also examined the number of hours for which teachers offered educational activities on this theme, prior to and following the elections, in social studies/sciences and cross-curricular projects, and related teacher aspirations. As mock elections are not mandatory, and we expected teachers to spend limited time on education activities, we developed the following response categories: 0 hours/0-1 hours/1-4 hours/More than 4 hours.

Because of the rather small research population and in order to support completion of the questionnaire, we did not demand from participants that they answer every question before proceeding. To increase the validity of the questionnaire, draft versions were discussed with experts from ProDemos, the education department at the University of Humanistic Studies, a number of teachers outside the research population (teachers in vocational education) and students in teacher training.

\section{Analysis}

For the analysis SPSS version 22 was used. From the list of teacher aims we distinguished 13 items that measure critical aims of democratic education (for example, 'An understanding of different types of reasons for people not to vote') and that had no missing scores. The 13 items were studied as a sum variable of which the alpha value was 0.91 . Similarly, we distinguished 13 items that were directed at strengthening a democratic school culture (for example, 'The ability to raise and address political issues in the own political community'). These items were also studied as a sum variable of which the alpha value was 0.95 . For both the teacher aims in the context of mock elections and the teacher aims that received little to no attention in the general curriculum, we calculated the means and standard deviations. Because of the missing scores on teacher aims in the mock election context, we could not examine which aims received little to no attention overall (in either the mock election context or the general curriculum) in participating schools. In order to define the percentage of teachers who paid little to no attention/some attention/ (very) much attention to specific aims in the context of mock elections, the original values were recoded into three categories.

To examine relations between the three school types and the categorical variable teachers' aims (more/less critical), the Chi-square test was used. Because specific teacher aims are measured at the ordinal level, the Kruskal-Wallis test was used to examine relations between these aims and school and teacher characteristics (for example, school types). To examine relations between educational activities and school and teacher characteristics, we used the Chi-square test.

\section{Results}

In the following sections we answer the research questions: (1) How do teachers (intend to) pursue critical aims and a democratic school culture in the mock elections context?;

(2) How many hours do teachers (intend to) offer educational activities in the mock elections context, and what educational activities do teachers (intend to) organize?; and (3) How do teacher aims and educational activities relate to teacher and school characteristics? In order to contextualize our findings, we first report on the teachers and schools that organize MEs in Dutch high schools. 


\section{Teacher and school characteristics}

Of the teachers organizing mock elections in our sample, a small majority are men (59 per cent, $N=57$ ). In terms of age, our teacher sample is balanced: 51 per cent of the teachers are aged 31 to 50 and 34 per cent are 51 or older. The others are aged 30 or younger. Further, 6 per cent of the teachers have a minority background (see Appendix 2). This percentage mirrors the general teacher population, as the 2009 diversity monitor revealed that 4.7 per cent of the people employed in secondary education are of non-Western origin (Van den Berg et al., 2011).

A slight majority of teachers are accredited social sciences teachers, while a large minority of the teachers have been teaching civics-related subjects for 11-20 years (see Appendix 2). Most respondents teach social studies, social sciences, or a combination of subjects. At a majority of schools, teachers indicate that the percentage of students with an immigrant background in their schools is below 25 per cent. Only 6 out of 96 teachers report to have a migrant background. As some of the teachers (10 per cent or more) were uncertain about the percentage of students from low income families and about the religious composition of the student population, we did not include these items in our analysis, given our limited sample size.

Comparing our school sample to the wider population of schools that organize mock elections reveals that our sample is geographically representative and mirrors the variety in school background among publicly funded schools in the Netherlands: denominational schools, open schools and non-traditional schools that are founded on pedagogical principles, for example, Montessori schools (see Appendix 3).

For our analysis of relations, we constructed three categories of schools that are sufficiently represented in our sample. The category 'comprehensive schools' $(N=35)$ contains schools that offer all education tracks (pre-vocational, general and preuniversity). Schools in the category 'pre-university education' ( $N=31$ ) offer only the general and/or pre-university education tracks. Schools in the category 'pre-vocational schools' ( $N=19)$ offer (part of) the pre-vocational tracks $1-4$. Vocational schools as well as schools for students with special educational needs $(N=11)$ were not included.

\section{Teacher aims in mock election-related education}

To answer question 1, we explored the critical aims and aims directed at strengthening a democratic school culture, hereby distinguishing between the knowledge, skills, and attitude and identity development that teachers pursue in the context of mock elections. Table 1 shows how 2 out of the 13 critical aims are well covered in the mock election context by over two-thirds of the teachers: 70 per cent explain that they (very) much foster students' willingness to talk with, and listen to, people who have fundamentally different ideas about political and existential issues; 69 per cent state that they foster the ability to judge the reliability of news on the elections on (social) media. It also shows how five of the critical aims receive attention by less than half of the teachers, and how attention varies widely amongst schools. Of the participating teachers, 48 per cent state that they foster an understanding of the implications of proposed policies for different groups of citizens, and 22 per cent give little to no attention to this aim. Where 47 per cent aim to advance students' ability to evaluate statements by citizens and politicians on political issues on (social) media in light of democratic principles, 23 per cent give little to no attention to this aim. While 43 per cent aim to foster students' personal views on principles that should (not) guide one's electoral participation, 22 per cent give little to no attention to this aim. Although 
35 per cent of the teachers aim to foster students' personal views on (un)desirable principles for sharing one's views on (social) media on political events, politicians and issues, 32 per cent give little to no attention to this aim. Finally, 29 per cent foster their personal views on (un)desirable principles for political actions directed at influencing the political agenda and political issues, while a larger group of teachers (41 per cent) gives little to no attention to this aim in the context of mock elections. Overall, 9 of the 13 critical aims receive little to no attention in the context of mock elections by 20-41 per cent of the teachers. This might relate to the fact that in the Netherlands social studies is mainly aimed at developing knowledge and analytical skills, and value education is not taught as a specific subject (Bron and Thijs, 2011; Veugelers et al., 2017).

\section{Table 1: Attention to critical aims}

\begin{tabular}{|c|c|c|c|c|}
\hline & $\mathbf{N}$ & $\begin{array}{l}\% \text { no/ } \\
\text { limited }\end{array}$ & $\%$ some & $\begin{array}{l}\% \text { (very) } \\
\text { much }\end{array}$ \\
\hline $\begin{array}{l}\text { The willingness to talk with, and listen to, people } \\
\text { who have fundamentally different ideas about } \\
\text { political and existential issues }\end{array}$ & 96 & 10 & 20 & 70 \\
\hline $\begin{array}{l}\text { The ability to judge the reliability of news on the } \\
\text { elections on (social) media }\end{array}$ & 96 & 12 & 20 & 69 \\
\hline $\begin{array}{l}\text { Insight into how students can respond to } \\
\text { prejudices and discrimination in light of the } \\
\text { principles of human dignity and respect }\end{array}$ & 96 & 20 & 24 & 56 \\
\hline $\begin{array}{l}\text { The ability to explain the election results in } \\
\text { a country/school in light of developments in } \\
\text { society, coverage of the elections on (social) } \\
\text { media and demographic circumstances }\end{array}$ & 96 & 18 & 25 & 56 \\
\hline $\begin{array}{l}\text { Insight into the interrelatedness of party } \\
\text { programmes and democratic principles }\end{array}$ & 96 & 20 & 26 & 54 \\
\hline $\begin{array}{l}\text { An understanding of different types of reasons } \\
\text { for people not to vote }\end{array}$ & 96 & 12 & 30 & 50 \\
\hline $\begin{array}{l}\text { The ability to nuance, defend and challenge a } \\
\text { statement about a proposed policy measure, } \\
\text { using argumentation skills }\end{array}$ & 96 & 13 & 27 & 50 \\
\hline $\begin{array}{l}\text { An understanding of the implications of } \\
\text { proposed policies for different groups of citizens }\end{array}$ & 96 & 22 & 28 & 48 \\
\hline $\begin{array}{l}\text { The ability to evaluate statements by citizens and } \\
\text { politicians on political issues on (social) media in } \\
\text { light of democratic principles }\end{array}$ & 96 & 23 & 30 & 47 \\
\hline $\begin{array}{l}\text { Personal views on principles that should (not) } \\
\text { guide one's electoral participation }\end{array}$ & 96 & 21 & 25 & 44 \\
\hline $\begin{array}{l}\text { Personal views on (un)desirable principles for } \\
\text { sharing one's views on (social) media on political } \\
\text { events, politicians and issues }\end{array}$ & 96 & 22 & 35 & 43 \\
\hline $\begin{array}{l}\text { Personal views on (un)desirable principles for } \\
\text { political actions directed at influencing the } \\
\text { political agenda and political issues }\end{array}$ & 96 & 32 & 33 & 35 \\
\hline $\begin{array}{l}\text { The ability to evaluate the quality of the political } \\
\text { institutions that one is part of in light of criteria of } \\
\text { a strong democratic community }\end{array}$ & 96 & 41 & 30 & 29 \\
\hline
\end{tabular}


Analysis of teacher aims that are particularly relevant to strengthening a democratic school culture reveals that four of these aims are well covered in the mock election context. Table 2 shows how 75 per cent of the teachers foster the ability to engage respectfully with people who hold fundamentally different political ideas in the context of mock elections; 70 per cent foster students' willingness to talk with, and listen to, people who hold fundamentally different ideas about political and existential issues; 69 per cent foster their willingness to examine different political perspectives; and 68 per cent foster students' ability to evaluate the quality of the political institutions that one is part of in light of criteria of a strong democratic community. Only 10-11 per cent of the teachers pay no or limited attention to these aims.

Table 2: Attention to aims directed at strengthening a democratic school culture

\begin{tabular}{|c|c|c|c|c|}
\hline & $\mathbf{N}$ & $\begin{array}{l}\% \text { no/ } \\
\text { limited }\end{array}$ & $\%$ some & $\begin{array}{l}\% \text { (very) } \\
\text { much }\end{array}$ \\
\hline $\begin{array}{l}\text { The ability to engage respectfully with people } \\
\text { who hold fundamentally different political ideas }\end{array}$ & 96 & 10 & 15 & 75 \\
\hline $\begin{array}{l}\text { The willingness to talk with, and listen to, people } \\
\text { who hold fundamentally different ideas about } \\
\text { political and existential issues }\end{array}$ & 96 & 10 & 20 & 70 \\
\hline $\begin{array}{l}\text { The willingness to examine different political } \\
\text { perspectives }\end{array}$ & 96 & 11 & 20 & 69 \\
\hline $\begin{array}{l}\text { The ability to evaluate the quality of the political } \\
\text { institutions that one is part of in light of criteria of } \\
\text { a strong democratic community }\end{array}$ & 96 & 10 & 12 & 68 \\
\hline $\begin{array}{l}\text { The ability to respond to prejudices and } \\
\text { discriminatory remarks, based on the principles of } \\
\text { shared human dignity and respect }\end{array}$ & 96 & 16 & 22 & 62 \\
\hline $\begin{array}{l}\text { The willingness to question one's own political } \\
\text { actions }\end{array}$ & 96 & 18 & 22 & 60 \\
\hline $\begin{array}{l}\text { Insight into how students can respond to } \\
\text { prejudices and discrimination in light of the } \\
\text { principles of human dignity and respect }\end{array}$ & 96 & 20 & 24 & 56 \\
\hline $\begin{array}{l}\text { An understanding of how school is also a political } \\
\text { community }\end{array}$ & 96 & 19 & 25 & 56 \\
\hline $\begin{array}{l}\text { Students' sense of political efficacy regarding } \\
\text { influencing decision-making in school }\end{array}$ & 83 & 14 & 30 & 56 \\
\hline $\begin{array}{l}\text { The ability to nuance, defend and challenge a } \\
\text { statement about a proposed policy measure, } \\
\text { using argumentation skills }\end{array}$ & 96 & 13 & 27 & 50 \\
\hline $\begin{array}{l}\text { The ability to evaluate statements by citizens and } \\
\text { politicians on political issues on (social) media in } \\
\text { light of democratic principles }\end{array}$ & 96 & 23 & 30 & 47 \\
\hline $\begin{array}{l}\text { The ability to evaluate one's contributions to the } \\
\text { political communities that one is part of }\end{array}$ & 96 & 32 & 29 & 39 \\
\hline $\begin{array}{l}\text { The ability to raise and address political issues in } \\
\text { one's own political community }\end{array}$ & 96 & 35 & 37 & 28 \\
\hline
\end{tabular}

Three of the aims directed at strengthening a democratic school culture are covered by less than 50 per cent of the teachers: 47 per cent of the teachers foster students' ability to evaluate statements by citizens and politicians on political issues on (social) 
media in light of democratic principles; 39 per cent foster their ability to evaluate one's contributions to the political communities that one is part of; and 28 per cent foster their ability to raise and address political issues in their own political community. We also found that four of the aims directed at strengthening a democratic school culture receive little to no attention by 20 per cent or more of the teachers: 20 per cent provide little to no support to students' insight into how students can respond to prejudices and discrimination in light of the principles of human dignity and respect in the mock election context; 23 per cent provide little to no support to students' ability to evaluate statements by citizens and politicians on political issues on (social) media in light of democratic principles; 32 per cent provide little to no support to students'; ability to evaluate one's contributions to the political communities that one is part of; and 32 per cent provide little to no support to students' ability to raise and address political issues in their own political community. This means that attention to these aims varies widely among schools.

\section{Teacher aims that are more or less neglected in the general curriculum}

To determine whether aims might be neglected in the mock election context because they are sufficiently covered in the general curriculum, we also explored which items receive little to no attention in the general curriculum. An analysis of the aims that receive little to no attention in the general curriculum does reveal a similar picture: one-third of the teachers report, for example, that both basic and critical knowledge aims receive limited attention in the general curriculum (see Appendix 1). Aims that are often mentioned in this regard $(N=40-6)$, and are thus least covered, are: knowledge about the background to the electoral system; limitations of different electoral and voting systems; criteria for fair elections; and envisioning the school as a political community.

\section{Educational activities}

This section answers the third research question: how many hours do teachers (intend to) devote to educational activities in the mock election context, and what types of educational activities do teachers (intend to) organize? An analysis of the number of hours devoted to education on mock elections in different education levels (preuniversity and pre-vocational) prior to the elections shows that 90 per cent of the preuniversity teachers and 80 per cent of the pre-vocational teachers devote attention to this theme in related subjects: social studies, social sciences and citizenship (social studies hereafter). It also shows that attention is not substantial in many schools. In the regular social studies classes, 51 per cent of the pre-university teachers and 62 per cent of the pre-vocational teaches spend less than one hour on this theme.

Among the teachers who primarily teach in higher secondary education $(N=86)$, three-quarters offer the following two educational activities: completing a voting advice application, to define which party matches your political views, and discussing political events, processes and practices in class (see also Table 3). Furthermore, over half of these teachers give individual or collaborative assignments about political events or practices, they have students discuss the rationale behind proposed policies and possible (unintended) implications of these policies, and they organize a political debate in class. Activities that are less frequently offered are individual/collaborative assignments on the desirability of proposed policies (30 per cent), and research, design, reflection and evaluative assignments $(20,36,31$ and 
22 per cent respectively). Likewise, fewer teachers organize activities that enable students to practise democracy; for instance a simulation or role play (31 per cent), a school level political debate (19 per cent) or a conference on a political issue (3 per cent). Furthermore, fewer teachers offer activities where students can interact with an expert/politician/guest speaker or visit a political organization or party bureau (27 and 16 per cent respectively).

We also found clear discrepancies (+33 percentage points) between the activities that teachers currently offer, and the activities that they would like to offer (ideal situation) for the following activities: research assignment; interaction with an expert/politician/guest speaker; organizing a political debate in school; visiting a political organization/party bureau; reflection assignment aimed at (de)constructing one's conceptions/understanding/views; (formative) evaluation assignment; conference on a political theme/the elections. The lower levels of secondary education show a similar pattern. Among the teachers who also teach the lower education levels $(N=38)$, scores on the ideal situation differ substantially from the current situation regarding inviting experts, organizing a political debate at school level, offering research and reflection assignments, organizing a conference on a political theme and visiting a political organization. This may relate to the lack of designated time for participatory practices and related education in the curriculum (see, for example, Veugelers et al., 2017).

Table 3: Learning activities in upper secondary education (levels 3 to 6)

\begin{tabular}{|c|c|c|c|c|c|}
\hline \multirow{2}{*}{$\begin{array}{l}\text { Learning activities levels 3-6 } \\
\text { Use Voter Application Tool }\end{array}$} & \multicolumn{2}{|c|}{$\begin{array}{c}\text { Current } \\
\text { ( } \mathrm{N} \text { and \%) }\end{array}$} & \multicolumn{2}{|c|}{$\begin{array}{c}\text { Ideal } \\
(\mathrm{N} \text { and \%) }\end{array}$} & \multirow{2}{*}{$\begin{array}{c}\text { Difference } \\
\text { in \% points } \\
-9\end{array}$} \\
\hline & 77 & 80 & 86 & 90 & \\
\hline $\begin{array}{l}\text { Individual/collaborative assignment on political } \\
\text { events, processes and practices }\end{array}$ & 65 & 68 & 76 & 79 & -11 \\
\hline $\begin{array}{l}\text { Individual/collaborative assignment on } \\
\text { desirable policies/implications of proposed } \\
\text { policies }\end{array}$ & 30 & 31 & 55 & 57 & -26 \\
\hline $\begin{array}{l}\text { Classroom discussion on political events, } \\
\text { processes and practices }\end{array}$ & 75 & 78 & 82 & 85 & -7 \\
\hline $\begin{array}{l}\text { Classroom discussion on background/ } \\
\text { implications of proposed policies }\end{array}$ & 50 & 52 & 62 & 65 & -13 \\
\hline Research assignment & 21 & 22 & 56 & 58 & -36 \\
\hline Design assignment & 36 & 38 & 59 & 61 & -24 \\
\hline $\begin{array}{l}\text { Reflection assignment, directed at } \\
\text { (de)construction of one's conceptions/ } \\
\text { understandings/views }\end{array}$ & 31 & 32 & 64 & 67 & -34 \\
\hline (Formative) evaluation assignment & 22 & 23 & 55 & 57 & -34 \\
\hline $\begin{array}{l}\text { Interaction with an expert/politician/guest } \\
\text { speaker }\end{array}$ & 27 & 28 & 79 & 82 & -54 \\
\hline Simulation or role play & 31 & 32 & 55 & 57 & -25 \\
\hline Political debate in class & 58 & 60 & 77 & 80 & -20 \\
\hline Political debate in school & 19 & 20 & 65 & 68 & -48 \\
\hline Conference on a political theme/the elections & 3 & 3 & 36 & 38 & -34 \\
\hline Visit to political organization/party bureau & 16 & 17 & 59 & 61 & -45 \\
\hline
\end{tabular}




\section{Interrelatedness of teacher aims and teacher and school characteristics}

This section reports the answers to the fourth research question: how do teacher aims and educational activities relate to teacher and school characteristics? Previous research suggests that civic education preserves or even widens the gap in civic opportunities among students attending pre-vocational and pre-university education tracks (see, for example, Kahne and Middaugh, 2008; Losito et al., 2018). In our study, we did not find a significant relation between school types and the overall teacher scores on critical aims and aims directed at strengthening a democratic school culture. Moreover, no significant relation was found between attention for critical aims and type of teacher training programme attended (social studies/other). This may relate to the limited time spent on education activities in the mock election context overall.

\section{Conclusion and discussion}

This article has reported the findings of a survey study into how teachers in secondary education in the Netherlands advance, and intend to advance, critical democratic citizenship and a democratic school culture in the context of mock elections. The analysis of survey data collected from teachers in 96 schools (which is a quarter of the research population) revealed that attention for critical, value-related teacher aims and teacher aims directed at strengthening a democratic school culture is still limited in mock election-related education. This suggests that there is limited attention for the moral-political, psychological and existential dimensions of democratic development and for strengthening a democratic (school) culture in mock electionrelated education. Furthermore, our findings indicate that in one-third of the schools, all 43 teacher aims receive limited attention in the general curriculum. Half of the participating schools offer less than one hour of mock election-related educational activities. We also identified a gap between the current and the desirable situation: one-third of the teachers would like to offer additional educational activities. In the following, we discuss our findings in light of recent studies on attention to democratic values in citizenship education and educational equality. We then discuss some limitations of the study and translate current insights into several recommendations for (inter)national policy and practice on mock elections and democratic education in general.

\section{Desirable practices}

Experts on student participation, student voice and human rights education have argued that schools need to provide opportunities for students to engage in meaningful participation in accordance with the age and maturity of the student (see, for example, UNCRC, 1989; Lundy, 2007). Five types of arguments can be distinguished in this regard (Bron and Veugelers, 2014): normative, developmental, political, educational and relevance, the latter concerning the significance of student participation for enhancing the quality of the curriculum. In this study we explored the educational dimension of student participation. Our findings indicate that in Dutch secondary education, mock elections are not widely used as a means to foster critical democratic development (educational dimension). This does not necessarily mean, however, that the participating schools do not have a strong civic profile. Schools may organize democratic participatory experiences and related educational 
activities in other projects and subjects. Furthermore, schools most likely focus on the aims as defined in curriculum guidelines, while part of the teacher aims in our survey (for example, one's personal views on principles that should (not) guide one's electoral participation) are not included in current social studies syllabi and guidelines on citizenship education (see, for example, Bron and Thijs, 2011; Veugelers et al., 2017). We are also aware that part of the critical aims (for example, 'the willingness to examine one's own political activities') may be too ambitious for young adolescents, and that teacher scores may have been higher if we had focused on the higher levels of secondary education. In itself, though, our finding on teacher willingness to offer more education activities suggests that stronger facilitation of mock elections will be helpful in strengthening this traditional type of political participatory 'education', for example, by increasing educational practices in the context of mock elections directed at developing elements of critical democratic citizenship and a democratic school culture.

With regard to the civic opportunity gap among pre-university and prevocational students, our findings show a mixed picture. Where both in the USA and in the Netherlands, scholars have noted lower (self)reported involvement by high school students from pre-vocational education tracks in civic/democratic activities in schools (Kahne and Middaugh, 2008; Munniksma et al., 2017), we did not find variation among school types in terms of the self-reported attention devoted to critical aims in the context of mock elections and of the educational activities offered. This suggests that, within our sample of mock election organizing schools, teachers from all school types intend to pursue critical aims to a similar degree. In this respect, our population of interest may differ from the general population of schools, which do not all organize mock elections. In addition, the gap in civic opportunities may well be present in the sampled schools as well, yet outside the context of mock elections. Our findings do indicate, however, that the civic opportunity gap among students from different education tracks is perpetuated, because half the participating schools offer less than one hour of mock election-related educational activities.

Our results also show a relatively low variety of activities organized in the context of mock elections, likely owing to a lack of available time, as teachers mark these activities as worthwhile. Discussions, political debates and assignments are most commonly used, while reflection, simulations and interaction with political organizations or guest speakers are much less frequently organized. These findings are in line with previous research on Dutch citizenship education. For instance, for six of the eight civic education activities reported in the ICCS study, Dutch schools score significantly lower than the ICCS average, including partaking in simulations. Moreover, only 13 per cent of Dutch students pay a visit to political institutions during secondary school, substantially below the ICCS average of 20 per cent (Munniksma et al., 2017).

\section{Limitations and suggestions for further research}

In this study we developed and piloted a questionnaire that captures key elements of democratic participatory education in schools from a critical democratic citizenship perspective. As our research sample was rather small $(N=96)$, we could not validate the instruments in the context of this study (for example, conduct factor analyses on the teacher aims). Follow-up studies with more cases are needed to gain insight into how attention to critical aims is distributed amongst school types. A third limitation of our study is that our sample only contained schools that organize elections using the ProDemos facilities. Schools that organize elections independently were not included in 
the study, and we have no data on schools that organize mock elections independently. We were also unable to include the school types that are underrepresented in our sample (practice-orientated pre-vocational education and vocational education) in our analysis of relations. Likewise, as there is no mandatory citizenship course in the lower levels of secondary education, our category of teachers who teach primarily in these lower levels was too small for a meaningful analysis of the educational activities organized prior to and after mock elections.

Future comparative studies can shed light on variations among countries in terms of current and ideal teacher aims and educational activities offered. Further educational design studies can also stimulate research-informed education in the context of mock elections, and can lead to evaluative research into whether and how such programmes influence the democratic development of students and the democratic culture of schools. It would also be relevant for the improvement of educational practice to gain further understanding into the value conflicts that teachers and school leaders face when introducing and organizing mock elections in schools.

\section{Recommendations for policy and practice}

Based on our findings and on knowledge from previous studies about citizenship education policies and practices internationally, we argue that there are ample opportunities in the Netherlands and internationally to strengthen the educational dimension of mock elections (through systematic support for the development of democratic competences) and to use mock elections as a means to strengthen the democratic culture in schools: for example, by creating opportunities for students to discuss and co-construct conceptions of democracy; to discuss political issues and the value of political conflict; to discuss current and desirable power inequalities in decision-making; to develop and challenge their own civic self-image; and to discuss and co-construct criteria for good political participation (Allen and Light, 2015; De Groot, 2017; Hess and McAvoy, 2015).

Ministries of Education, school leaders and teachers in the Netherlands and elsewhere could stimulate this development by designating spaces in the curriculum, also at lower education levels, to offer mock elections and other democratic participatory practices (for example, election simulations or mock courts). More generally, school leaders, teachers and NGOs can also facilitate student deliberation on issues that affect the learning, social and democratic climate in school. At the policy level this means that the government should consider imposing requirements with respect to the quantity and quality of opportunities for all students to experience and practice democracy. A second measure that might be helpful to strengthen opportunities for democratic participatory education is to create further opportunities for teachers to advance their ability to organize and guide democratic practices and experiences. Promising initiatives in the Netherlands in this regard are the teacher workgroup (curriculum.nu), recently appointed by the Dutch Ministry of Education, which is currently defining the key aims and principles of democratic education in consultation with a wide range of educational partners, as well as the current revision of citizenship education legislation in the Netherlands. The findings of this study have also inspired ProDemos to develop additional value-related democratic education materials. We hope that these initiatives will contribute to strengthening the impact of mock elections. 


\section{Acknowledgement}

This study was co-funded by the University of Humanistic Studies and ProDemos.

\section{Notes on the contributors}

Isolde de Groot is Assistant Professor at the University of Humanistic Studies. Her research addresses issues in democratic citizenship education, identity development and narrative learning.

Bram Eidhof is Assistant Professor at the University of Humanistic Studies. His main interests lie in democratic citizenship education, educational inequalities and inclusive education.

\section{References}

Allen, D. and Light, J.S. (eds) (2015) From Voice to Influence: Understanding citizenship in a digital age. Chicago: University of Chicago Press.

Barron, B.J.S., Schwartz, D.L., Vye, N.J., Moore, A., Petrosino, A., Zech, L., Bransford, J.D. and the Cognition and Technology Group at Vanderbilt (1998) 'Doing with understanding: Lessons from research on problem- and project-based learning'. Journal of the Learning Sciences, 7 (3-4), 271-311.

Biesta, G.J.J. (2011) Learning Democracy in School and Society: Education, lifelong learning, and the politics of citizenship. Rotterdam: Sense Publishers.

Bîrzea, C. (2005) Learning Democracy: Education policies within the Council of Europe. Strasbourg: Council of Europe.

Bloom, B.S. (1956) Taxonomy of Educational Objectives: The classification of educational goals. New York: Longman.

Bron, J. and Thijs, A. (2011) 'Leaving it to the schools: Citizenship, diversity and human rights education in the Netherlands'. Educational Research, 53 (2), 123-36.

Bron, J. and Veugelers, W. (2014) 'Why we need to involve our students in curriculum design: Five arguments for student voice'. Curriculum and Teaching Dialogue, 16 (1), 125-39.

Carretero, M., Haste, H. and Bermudez, A. (2015) Civic Education. In L. Corno \& E. Anderman (eds), Handbook of Educational Psychology (pp. 295-308). Abingdon: Taylor \& Francis.

De Groot, I. (2013) 'Adolescents' Democratic Engagement: A qualitative study into the lived citizenship of adolescents in the Dutch democratic pluralist society'. Unpublished PhD thesis, Universiteit voor Humanistiek, Utrecht.

De Groot, I. (2017) 'Mock elections in civic education: A space for critical democratic citizenship development'. Journal of Social Science Education, 16 (3), 84-96.

De Groot, I. (2018a) 'Narrative learning for democratic citizenship identity: A theoretical framework'. Educational Review, 70 (4), 447-64.

De Groot, I. (2018b) 'Political simulations: An opportunity for meaningful democratic participation in schools'. Democracy and Education, 26 (2), Article 3, 1-11. Online. https://tinyurl.com/y5vd4fwl (accessed 20 July 2019).

De Groot, I. and Veugelers, W. (2015) 'Why we need to question the democratic engagement that adolescents in Europe develop'. Journal of Social Sciences Education, 14 (4), 27-38.

Dekker, S. (2015) Kamerbrief Voortgang versterking burgerschapsvorming in het onderwijs [Strengthening Citizenship education in the Netherlands]. Den Haag: Ministerie van OC\&W.

Dewey, J. (1916) Democracy and Education: An introduction to the philosophy of education. New York: Macmillan.

Educational Inspectorate (2016) Burgerschap in School. Een beschrijving van burgerschapsonderwijs en de maatschappelijke stage. Den Haag: MOC\&W

Educational Research Service (1997) Higher Order Thinking Skills. Arlington, VA: Educational Research Service.

Fielding, M. and Moss, P. (2012) 'Radical democratic education'. Paper presented at the American Sociological Association (ASA) Annual Meeting, Denver, Colorado, 17-20 August 2012. Online. https://tinyurl.com/ybyzzn3k (accessed 20 July 2019). 
Hattie, J. (2012) Visible Learning for Teachers: Maximizing impact on learning. London: Routledge.

Hess, D.E. and McAvoy, P. (2015) The Political Classroom: Evidence and ethics in democratic education. New York: Routledge.

Kahne, J. and Middaugh, E. (2008) Democracy for Some: The civic opportunity gap in high school (CIRCLE Working Paper 59). Medford, MA: Center for Information and Research on Civic Learning and Engagement.

Keating, A. and Janmaat, J.G. (2016) 'Education through citizenship at school: Do school activities have a lasting impact on youth political engagement?'. Parliamentary Affairs, 69 (2), 409-29.

Lo, J.C. (2017) 'Empowering young people through conflict and conciliation: Attending to the political and agonism in democratic education'. Democracy and Education, 25 (1), Article 2.

Losito, B., Agrusti, G., Damiani, V. and Schulz, W. (2018) Young People's Perceptions of Europe in a Time of Change: IEA International Civic and Citizenship Education Study 2016 European report. Amsterdam: International Association for the Evaluation of Educational Achievement.

Lundy, L. (2007) "“Voice" is not enough: Conceptualising Article 12 of the United Nations Convention on the Rights of the Child'. British Educational Research Journal, 33 (6), 927-42.

Ministry of Education (2006) Toezichtkader actief burgerschap en sociale integratie. Staatscourant 128, 1-6. Den Haag: Ministerie van OC\&W.

Munniksma, A., Dijkstra, A.B., Van der Veen, I., Ledoux, G., Van de Werfhorst, H. and Ten Dam, G. (2017) Burgerschap in het voortgezet onderwijs: Nederland in vergelijkend perspectief. Amsterdam: Amsterdam University Press.

Parker, W.C. (2003) Teaching Democracy: Unity and diversity in public life. New York: Teachers College Press.

Parker, W.C. and Lo, J.C. (2016) 'Reinventing the high school government course: Rigor, simulations, and learning from text'. Democracy and Education, 24 (1), Article 6, 1-10. Online. https://tinyurl.com/y5qsokuk (accessed 24 July 2019).

Percy-Smith, B. and Thomas, N. (2012) A Handbook of Children and Young People's Participation: Perspectives from theory and practice. London: Routledge.

Schulz, W., Ainley, J., Fraillon, J., Losito, B. and Agrusti, G. (2016) IEA International Civic and Citizenship Education Study 2016 Assessment Framework. Cham: Springer International Publishing.

Shier, H. (2001) 'Pathways to participation: Openings, opportunities and obligations'. Children and Society, 15 (2), 107-17.

UNCRC (United Nations Convention on the Rights of the Child) (1989) London: Unicef. Online. https://tinyurl.com/y4jqc66s (accessed 20 May 2019).

Van den Berg, D., Van Dijk, M. and Grootscholte, M. (2011) Diversiteitsmonitor 2011: Cijfers en feiten over diversiteit in het po, vo, mbo en op lerarenopleidingen: Een update van de Diversiteitsmonitor 2010. Den Haag: Sectorbestuur Onderwijsarbeidsmarkt.

Veugelers, W., De Groot, I. and Stolk, V. (2017) Research for CULT Committee: Teaching common values in Europe: Study. Brussels: Policy Department for Structural and Cohesion Policies, European Parliament.

\section{Appendices}

\section{Appendix 1: Teacher aims}

\section{A: Knowledge aims of teachers}

\begin{tabular}{|c|c|c|c|c|c|c|c|}
\hline & \multicolumn{3}{|c|}{$\begin{array}{l}\text { Attention in mock } \\
\text { election context }\end{array}$} & \multicolumn{3}{|c|}{$\begin{array}{l}\text { No/limited attention in } \\
\text { the general curriculum }\end{array}$} & \multirow{2}{*}{$\begin{array}{l}\text { Difference } \\
\qquad \mathrm{N}\end{array}$} \\
\hline & $\mathrm{N}$ & $\mathrm{M}$ & SD & $N$ & $\mathrm{M}$ & SD & \\
\hline $\begin{array}{l}\text { Knowledge about key } \\
\text { features of parliamentary } \\
\text { democracy }\end{array}$ & 87 & 4.11 & .75 & 36 & 1.92 & .28 & 51 \\
\hline $\begin{array}{l}\text { Knowledge about the } \\
\text { structure of representative } \\
\text { democracy in the }\end{array}$ & 87 & 3.99 & .91 & 35 & 1.94 & .24 & 52 \\
\hline
\end{tabular}

Netherlands 
Knowledge about

political parties and party

89

4.19

.78

34

1.85

55

programmes

Insight into the

interrelatedness of

party programmes and

democratic principles

Insight into policy

development procedures

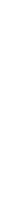

implications of proposed

policies for different

groups of citizens

Knowledge about criteria

for fair elections

Knowledge about

the election system

and procedures in the

Netherlands

Knowledge about the

rationale behind the

current election system

and procedures

Knowledge about

alternative election

systems and procedures

Insight into limitations of

different election systems

and election procedures

Knowledge about the

political rights of Dutch

citizens

An understanding of

different types of reasons

for people not to vote

An understanding

of different types of

arguments that can

$\begin{array}{lllllll}84 & 3.32 & 1.11 & 38 & 1.74 & .45 & 46\end{array}$

$\begin{array}{lllllll}96 & 2.85 & 1.54 & 45 & 1.60 & .50 & 51\end{array}$

$\begin{array}{lllllll}86 & 3.63 & .96 & 40 & 1.78 & .42 & 46\end{array}$

$\begin{array}{lllllll}87 & 3.66 & .97 & 42 & 1.62 & .49 & 45\end{array}$

$\begin{array}{lllllll}82 & 3.17 & 1.26 & 45 & 1.58 & .50 & 37\end{array}$

$\begin{array}{lllllll}84 & 2.81 & 1.29 & 42 & 1.48 & .51 & 42\end{array}$

$\begin{array}{lllllll}84 & 2.87 & 1.21 & 46 & 1.50 & .51 & 38\end{array}$

$\begin{array}{lllllll}86 & 3.88 & .80 & 35 & 1.91 & .28 & 51\end{array}$

$\begin{array}{lllllll}96 & 3.00 & 1.44 & 37 & 1.59 & .50 & 59\end{array}$

influence voting behaviour

Insight into how students

can respond to prejudices

and discrimination in light

of the principles of human

$\begin{array}{lllllll}96 & 3.14 & 1.50 & 39 & 1.82 & .39 & 57\end{array}$

dignity and respect

An understanding of other ways (apart from voting/ becoming a politician)

for citizens to influence

decision-making in politics

An understanding of the

Netherlands as a political

community

88

3.661 .00

.00

37

$\begin{array}{ll}1.76 & .44\end{array}$

51

An understanding of

schools as political

communities

$\begin{array}{llllll}96 & 2.68 & 1.46 & 40 & 1.43 & .50\end{array}$

56 


\begin{tabular}{|c|c|c|c|c|c|c|c|}
\hline \multicolumn{8}{|c|}{ 1B: Skills related teacher aims } \\
\hline \multirow[b]{2}{*}{ The ability to } & \multicolumn{3}{|c|}{$\begin{array}{l}\text { Attention in mock } \\
\text { election context }\end{array}$} & \multicolumn{3}{|c|}{$\begin{array}{l}\text { No/limited attention in } \\
\text { general curriculum }\end{array}$} & \multirow{2}{*}{$\begin{array}{c}\text { Difference } \\
\qquad \mathrm{N}\end{array}$} \\
\hline & $\mathrm{N}$ & GEM & SD & $\mathrm{N}$ & GEM & SD & \\
\hline $\begin{array}{l}\text { Recognize and explain } \\
\text { party programmes and } \\
\text { political perspectives }\end{array}$ & 86 & 4.02 & .894 & 34 & 1.88 & .327 & 52 \\
\hline $\begin{array}{l}\text { Question the results of } \\
\text { voting advice applications }\end{array}$ & 86 & 3.57 & 1.080 & 37 & 1.41 & .498 & 49 \\
\hline $\begin{array}{l}\text { Position oneself in the } \\
\text { political landscape }\end{array}$ & 86 & 3.99 & .988 & 37 & 1.70 & .463 & 49 \\
\hline $\begin{array}{l}\text { Judge the reliability of } \\
\text { 'information' on social } \\
\text { media }\end{array}$ & 96 & 3.40 & 1.476 & 41 & 1.76 & .435 & 55 \\
\hline $\begin{array}{l}\text { Nuance, defend and } \\
\text { challenge a statement } \\
\text { about a proposed } \\
\text { policy measure, using } \\
\text { argumentation skills }\end{array}$ & 96 & 2.90 & 1.606 & 39 & 1.64 & .486 & 57 \\
\hline $\begin{array}{l}\text { Explain the election } \\
\text { results in a country/ } \\
\text { school in light of } \\
\text { developments in society, } \\
\text { news-coverage on (social) } \\
\text { media and demographic } \\
\text { circumstances }\end{array}$ & 96 & 2.99 & 1.593 & 38 & 1.58 & .500 & 58 \\
\hline $\begin{array}{l}\text { Evaluate statements by } \\
\text { citizens and politicians } \\
\text { on (social) media using } \\
\text { democratic principles }\end{array}$ & 96 & 2.64 & 1.668 & 34 & 1.65 & .485 & 62 \\
\hline $\begin{array}{l}\text { Engage respectfully } \\
\text { with people who hold } \\
\text { fundamentally different } \\
\text { political ideas }\end{array}$ & 96 & 3.21 & 1.660 & 35 & 1.80 & .406 & 61 \\
\hline $\begin{array}{l}\text { Respond to prejudices } \\
\text { and discrimination in } \\
\text { light of the principles } \\
\text { of equality, dignity and } \\
\text { respect }\end{array}$ & 96 & 3.07 & 1.578 & 34 & 1.79 & .410 & 62 \\
\hline $\begin{array}{l}\text { Evaluate the quality of the } \\
\text { political communities in } \\
\text { light of criteria of a strong } \\
\text { democratic community }\end{array}$ & 96 & 2.30 & 1.516 & 39 & 1.41 & .498 & 57 \\
\hline $\begin{array}{l}\text { Evaluate one's } \\
\text { contributions to the } \\
\text { political communities that } \\
\text { one is part of }\end{array}$ & 96 & 2.51 & 1.589 & 36 & 1.50 & .507 & 60 \\
\hline $\begin{array}{l}\text { Raise and address political } \\
\text { issues in one's own } \\
\text { political community }\end{array}$ & 96 & 2.34 & 1.514 & 38 & 1.53 & .506 & 58 \\
\hline
\end{tabular}




\begin{tabular}{|c|c|c|c|c|c|c|c|}
\hline \multicolumn{8}{|c|}{ 1C: Attitude and identity related teacher aims } \\
\hline & \multicolumn{3}{|c|}{$\begin{array}{l}\text { Attention in mock } \\
\text { election context }\end{array}$} & \multicolumn{3}{|c|}{$\begin{array}{l}\text { No/limited attention in } \\
\text { general curriculum }\end{array}$} & \multirow{2}{*}{$\begin{array}{l}\text { Difference } \\
\text { N }\end{array}$} \\
\hline & $\mathrm{N}$ & M & SD & $\mathrm{N}$ & M & SD & \\
\hline $\begin{array}{l}\text { Reflectively constructed } \\
\text { attitude regarding the } \\
\text { right to vote }\end{array}$ & 83 & 4.02 & .765 & 34 & 1.88 & .327 & 49 \\
\hline $\begin{array}{l}\text { Reflectively constructed } \\
\text { attitude regarding the } \\
\text { democratic political } \\
\text { system and its officials }\end{array}$ & 81 & 3.81 & .950 & 33 & 1.85 & .364 & 48 \\
\hline $\begin{array}{l}\text { Commitment to the well- } \\
\text { being of the national } \\
\text { political community }\end{array}$ & 84 & 3.69 & 1.018 & 32 & 1.59 & .499 & 52 \\
\hline $\begin{array}{l}\text { Commitment to the well- } \\
\text { being of minority groups } \\
\text { within the national/local } \\
\text { political community }\end{array}$ & 83 & 3.45 & 1.129 & 36 & 1.69 & .467 & 47 \\
\hline $\begin{array}{l}\text { Commitment to the well- } \\
\text { being of groups of people } \\
\text { elsewhere }\end{array}$ & 81 & 3.17 & 1.223 & 36 & 1.61 & .494 & 45 \\
\hline $\begin{array}{l}\text { The willingness to } \\
\text { examine different political } \\
\text { perspectives }\end{array}$ & 96 & 3.19 & 1.637 & 35 & 1.66 & .482 & 61 \\
\hline $\begin{array}{l}\text { The willingness to speak } \\
\text { and listen to people } \\
\text { who hold fundamentally } \\
\text { different ideas about } \\
\text { political and existential } \\
\text { issues }\end{array}$ & 96 & 3.28 & 1.574 & 33 & 1.67 & .479 & 63 \\
\hline $\begin{array}{l}\text { The willingness to } \\
\text { question one's own } \\
\text { political actions }\end{array}$ & 96 & 2.91 & 1.686 & 34 & 1.56 & .504 & 62 \\
\hline $\begin{array}{l}\text { Students' sense of political } \\
\text { efficacy regarding their } \\
\text { influence on political } \\
\text { decision-making at the } \\
\text { local/national level }\end{array}$ & 83 & 3.48 & 1.028 & 34 & 1.71 & .462 & 49 \\
\hline $\begin{array}{l}\text { Students' sense of political } \\
\text { efficacy regarding their } \\
\text { influence on decision- } \\
\text { making in school }\end{array}$ & 96 & 2.76 & 1.554 & 35 & 1.66 & .482 & 61 \\
\hline $\begin{array}{l}\text { Students' views on } \\
\text { principles that should } \\
\text { (not) guide one's electoral } \\
\text { participation }\end{array}$ & 96 & 2.51 & 1.673 & 38 & 1.53 & .506 & 58 \\
\hline $\begin{array}{l}\text { Students' views on } \\
\text { principles that should } \\
\text { (not) inform one's political } \\
\text { participation on social } \\
\text { media }\end{array}$ & 96 & 2.75 & 1.576 & 37 & 1.51 & .507 & 59 \\
\hline
\end{tabular}


Students' views on principles that should (not) inform one's activities directed at influencing

political agendas and addressing political issues

\section{Appendix 2: Teacher and school characteristics}

\begin{tabular}{|c|c|c|}
\hline & Percentage & $\mathrm{n}$ \\
\hline \multicolumn{3}{|l|}{ Age } \\
\hline$<30$ & 15.6 & 15 \\
\hline $31-40$ & 24.0 & 23 \\
\hline $41-50$ & 27.1 & 26 \\
\hline $51-60$ & 19.8 & 19 \\
\hline$>61$ & 13.5 & 13 \\
\hline Missing & 0.0 & 0 \\
\hline \multicolumn{3}{|l|}{ Gender } \\
\hline Male & 59.4 & 57 \\
\hline Female & 40.6 & 39 \\
\hline Missing & 0.0 & 0 \\
\hline \multicolumn{3}{|l|}{ Migrant background } \\
\hline Yes & 6.3 & 6 \\
\hline No & 81.3 & 78 \\
\hline Missing & 12.5 & 12 \\
\hline \multicolumn{3}{|l|}{ Accredited social studies teacher } \\
\hline Yes & 57.3 & 55 \\
\hline No & 35.4 & 34 \\
\hline Missing & 7.3 & 7 \\
\hline \multicolumn{3}{|l|}{ Years' experience in teaching civics } \\
\hline $0-10$ & 51.0 & 49 \\
\hline $11-20$ & 27.1 & 26 \\
\hline$>20$ & 20.8 & 20 \\
\hline Missing & 1.0 & 1 \\
\hline \multicolumn{3}{|l|}{ Denomination } \\
\hline Public & 42.7 & 41 \\
\hline Christian & 45.8 & 44 \\
\hline Non-traditional (Dalton, Montessori, etc.) & 10.4 & 10 \\
\hline Other & 1.0 & 1 \\
\hline Missing & 0.0 & 0 \\
\hline \multicolumn{3}{|l|}{ Student population size } \\
\hline$<500$ & 25.0 & 24 \\
\hline 500-999 & 24.0 & 23 \\
\hline $1,000-1,500$ & 29.2 & 28 \\
\hline$>1,500$ & 20.8 & 20 \\
\hline Missing & 1.0 & 1 \\
\hline
\end{tabular}




\begin{tabular}{lcc}
\hline & Percentage & $\mathbf{n}$ \\
\hline Est. \% of students with migration background & & \\
$<25 \%$ & 78.1 & 75 \\
$25-49 \%$ & 10.4 & 10 \\
$50-75 \%$ & 1.0 & 1 \\
$>75 \%$ & 1.0 & 8 \\
I don't know & 8.3 & 1 \\
Missing & 1.0 & \\
\hline
\end{tabular}

Appendix 3: Comparison of population and sample

\begin{tabular}{lccc}
\hline Province & \% in population & \% in sample & $\begin{array}{c}\text { Difference in \% } \\
\text { points }\end{array}$ \\
\hline Groningen & 3.0 & 2.1 & 0.9 \\
Friesland & 5.0 & 5.2 & -0.2 \\
Drenthe & 2.8 & 2.1 & 0.7 \\
Flevoland & 2.8 & 3.1 & -0.3 \\
Noord-Holland & 16.5 & 12.5 & 4.0 \\
Overijssel & 6.5 & 11.5 & -5.0 \\
Gelderland & 13.9 & 13.5 & 0.4 \\
Utrecht & 8.1 & 11.5 & -3.4 \\
Noord-Brabant & 13.9 & 15.6 & -1.7 \\
Limburg & 2.2 & 1.0 & 1.2 \\
Zeeland & 1.4 & 2.1 & -0.7 \\
Zuid-Holland & 23.6 & 19.8 & 3.8 \\
\hline & & & Difference in \% \\
\hline & & & points \\
\hline Denomination & \% in population & \% in sample & 0.3 \\
Christian & 46.1 & 45.8 & -2.5 \\
Non-traditional (Dalton, etc.) & 7.9 & 10.4 & -1.7 \\
Public & 41.0 & 42.7 & 4.1 \\
Other & 5.1 & 1.0 & \\
\hline
\end{tabular}

Note that the population of interest consists of schools in the Netherlands that organize mock elections. 